\title{
The Principal's Strategy for Improving the Quality of Education: A Study at MTs Asy-Asyafiiyah Kendari
}

\author{
Nadia Ayu Pratiwi \\ Universitas Halu Oleo \\ email: ayunadia091@gmail.com
}

\begin{abstract}
This article aims to describe: 1) the strategy of the madrasah head in improving the quality of education in MTs Asy-Syafiiyah Kendari; 2) supporting and inhibiting factors in improving the quality of education in MTs Asy-Syafiiyah Kendari; 3) the impact of implementing the Madrasah Kapala strategy on improving the quality of education in Ass-Asyafiiyah Kendari MTs. This research is a qualitative research, in which data is collected through interviews, observations, and document studies. The collected data is analyzed through the process of data reduction, data display, and data verification. The results showed: 1) the principal's strategy in improving the quality of education is seen in the vision and policies of quality-oriented schools, exploring student competencies, developing teacher competencies, and establishing partnerships; 2) a supporting factor in improving the quality of education is the leadership of the principal who focuses on the quality and support of the community. While the inhibiting factors are quality awareness not yet evenly distributed to all school residents; 3) The principal's strategy has an impact on the recognition of MTs Asy-Syafiiyah by the community, increasing graduation rates, increasing work partners, improving the development of students' talent interests, and increasing teacher competency.
\end{abstract}

Keywords: Madrasah Head Strategy, Quality of Education 


\section{Abstrak}

Artikel ini bertujuan menggambarkan tentang: 1) strategi kepala madrasah dalam meningkatkan mutu pendidikan di MTs AsySyafiiyah Kendari; 2) faktor pendukung dan penghambat dalam meningkatkan mutu pendidikan di MTs Asy-Syafiiyah Kendari; 3) dampak penerapan strategi kapala madrasah terhadap peningkatan mutu pendidikan di MTs Asy-Asyafiiyah Kendari. Penelitian ini merupakan penelitian kualitatif, yang mana data dikumpulkan melalui wawancara, pengamatan, dan studi dokumen. Data yang terkumpul dianalisis melalui proses reduksi data, display data, dan verifikasi data. Hasil penelitian menunjukkan : 1) strategi kepala sekolah dalam meningkatkan mutu pendidikan terlihat pada visi dan kebijakan sekolah yang berorientasi mutu, menggali kompetensi peserta didik, pengembangan kompetensi guru, dan menjalin kemitraan; 2) faktor pendukung dalam peningkatan mutu pendidikan adalah kepemimpinan kepala sekolah yang fokus pada mutu dan dukungan masyarakat. Sedangkan faktor penghambat adalah kesadaran mutu belum merata pada semua warga sekolah; 3) Strategi kepala sekolah berdampak pada semakin dikenalnya MTs Asy-Syafiiyah oleh masyarakat, peningkatan tingkat kelulusan, peningkatan mitra kerja, perbaikan pengembangan minat bakat peserta didik, dan peningkatan kompetensi guru.

Kata Kunci: Strategi Kepala Madrasah, Mutu Pendidikan 


\section{Introduction}

The principal has a very decisive role in the back and forth of an educational institution. One measure of the progress of an educational institution is the quality of the school. So that the principal has a direct relationship with all activities related to the quality of education, especially the quality of schools (Fitrah, 2017). Various activities of school principals in improving the quality of education include increasing teacher professionalism (Mulyana, 2014), improving the quality of the learning process (Triyanto \& Suryani, 2013), increase work motivation (Setiyati, 2014), build and maintain school culture (Setiyati, 2014), and improving teacher performance (Sulistiya, 2013). The complexity of the roles of school principals shows the extent of matters that must be handled by the principal, namely those related to education and learning, school management, administration, supervision, leading, innovation, and encouraging improvements in the performance of school members (Nurhayati, 2019).

The principal is the key that determines the success of the school in achieving its goals (Ekosiswoyo, 2016). Therefore, the principal is required to always improve the effectiveness of the performance of the staff in the school. Seeing the importance and strategic position of the principal in realizing school goals, the principal should have the ability to have good relations with all school residents, so that school and education goals can be achieved optimally. The principal is a central figure in the school. In a more strategic context, the principal or madrasah has a direct influence on teacher performance (Iskandar, 2013), even school accountability (Bafadal, 2016).

The context of madrasah is not much different from that of general schooling. The role of the head of madrasah in improving the quality of madrasah is very much needed, considering that madrasahs have demands to be able to stand on an equal footing with nonmadrasah schools (Fauzi, 2017). Competition between Islamic educational institutions is also very tight, with the emergence of various Islamic educational institutions offering a very varied menu. The position of the madrasa leader in this case is not only as a formal leader but also an example of creative, adaptive and innovative leadership (Syahrul, 2015). 
The problem to be addressed in this study is how to improve the quality strategy at MTs Asy-Syafiiyah Kendari. In this case, what is the actual strategy carried out by the principal as a leader in improving the quality of Islamic religious education learning so that Islamic religious education in schools can run well and in accordance with the objectives to be achieved.

The principal as the education leader is the person most responsible for the success of education in his school. The principal is concerned with leadership in carrying out tasks and relationships between people. Then the conditions that must be met by someone who is elected or appointed as the principal must have the ability to carry out duties and the ability to foster good relationships with all school personnel (Setiyati, 2014). Principal leadership in education includes the process of moving, influencing, motivating and directing people in educational organizations / institutions, especially to achieve the goals that have been formulated. Thus it can be concluded that an educational leader in this case is the principal is required to have the ability to guide, mobilize and encourage and direct people in educational institutions, namely achieving educational goals that have been previously formulated (Ekosiswoyo, 2016).

Based on the functions and objectives of education in the National Education System Law, MTs Asy-Syafiiyah formulates a vision of realizing a cheerful (smart, accomplished, Islamic, shady and beautiful) madrasa with an environmental perspective. By analyzing the potential that exists in MTs Asy-Syafi'iyah Kendari, both in terms of input / new students, competence of teaching staff, education staff, madrasah environment, community participation, and the outcomes of MTs graduates. Asy-Syafi'iyah Kendari, the community around the religious school, and through intensive communication and coordination between madrasas with madrasah residents and with stakeholders, a vision of the madrasah was compiled.

Based on preliminary observations made by researchers at MTs Asy-Syafiiyah Kendari, it is seen that the madrasah has the potential to become an educational institution that can be recognized for its credibility and grow into one of the leading schools. This can be seen from the strategy and school management in improving the quality of education, as seen from the fact that the researchers found that MTs Asy-Syafiiyah is one of the environmentally friendly madrasas, has internal strength such as adequate human resources and 
has good abilities, have students or students who have high enthusiasm so that they can achieve several achievements. Like the steel champion of poetry, speeches, sports, kasidah, and recitation of the Qur'an, has sufficient resources and infrastructure to support all activities that exist in madrassas even though the environment is not so broad, in the midst of the environment. a market that seems free and wild, is able to lead students to remain disciplined and not be influenced by the environment.

Based on the findings of facts in the field, researchers are interested in deeper research related to these problems by taking the title Research Principal Strategy in Improving the Quality of Education in MTs Asy-Asyafiiyah Kendari.

\section{Method}

This type of research is a qualitative descriptive study, which is a type of research that describes the real conditions of the research title or research object based on original or natural data (Bungin, 2007). This study does not use numbers in its collection. This research describes the things that happen by using words or sentences. The approach used in this research is a case study. This approach is an approach used to interpret conditions or circumstances on the object of research. This approach aims to interpret and describe the object under study. This approach is carried out using data collection methods such as observation, interviews and documentation (Sugiyono, 2010). Therefore, researchers used this approach to answer questions about how professionalism of certified teachers is, how the impact of certified teacher professionalism on student achievement at MTs AsySyafiiyah Kendari.

The types of data in this study consisted of two types, namely primary data and secondary data. The data sources for each type of data are as follows:

1. Primary data or main data obtained from the results of field observations and interviews with research informants such as certified teachers at MTs Asy-Syafiiyah Kendariu Regency, and school principals as cross check materials. The data sources in the primary data are the principal, 5 certified teachers, and 5 students.

2. Secondary data or supporting data is data obtained from documentation. The data sources in secondary data are school documents / archives, teacher teaching journals, teacher absences, 
student report cards, and literature reference materials relevant to the research title.

In data collection, researchers used the following methods:

1. Observation, namely observing various phenomena that occur in the field. The phenomenon in question is related to the professionalism of certified teachers at MTs Asy-Syafiiyah Kendari. Observation activities were carried out at MTs AsySyafiiyah Kendari, which served as a research site. These observations are carried out as a reliable source of additional information and a means of documenting, as for the objects of observation, namely the school environment, student learning environment, teacher discipline, teacher activities in learning activities including teacher activeness in preparing learning devices, and student conditions during learning activities.

2. Interview, namely conducting direct questions and answers with a number of informants who are believed to have knowledge of the problems being researched regarding the professionalism of certified teachers at MTs Asy-Syafiiyah Kendari. The type of interview used is in-depth interview, which is an interview conducted face-to-face between the interviewer and the informant, with or without using an in-depth interview guide with the aim of obtaining a large amount of information data. The interview was conducted at MTs Asy-Syafiiyah Kendari when the teacher was not teaching and during recess. Interview activities were carried out to complete the incomplete initial information and to obtain more indepth, comprehensive, accurate and honest information. The informants or data sources from this interview were the principal, certified teachers and students.

3. Documentation, which is finding the data needed by the researcher as a complement to the research. This technique is used to find out the professionalism of certified teachers through archives or data about their educational background and teaching experience at MTs Asy-Syafiiyah Kendari. Some of the documents that can be collected are documents in the form of writing such as school documents / archives, documents in the form of images that support research data such as certified teacher activities in teaching, and electronic documents such as recorded interviews.

After collecting data, the researcher performs processing and checks the validity of the data. In processing and checking the validity 
of the data, researchers used techniques from Milles and Huberman which consisted of three parts, namely :

1. Data collection, namely the process of obtaining and collecting information data needed in order to achieve research objectives.

2. Data reduction, namely the research process, focusing on simplification, abstracting and transforming "rough" data that emerge from the writer's notes in the field. In addition, reduction is also intended to sharpen, classify, direct, remove unnecessary and organize data in such a way that final conclusions can be drawn and verified.

3. Presentation of data, after the researcher performs data reduction, what is done next is to present the data in the form of a brief description or the like. By displaying the data, it will be easier to understand what happened, plan the next work based on what is understood.

4. Withdrawing conclusions, the final step of data analysis and processing is drawing conclusions, this technique is used to draw conclusions from the data that has been compiled so that researchers can produce conclusions as desired. The researcher uses this conclusion to answer the research problem and draws final conclusions from the research data (Miles \& Huberman, 1984).

\section{Research result}

\section{A. Strategy for Improving the Quality of Education at MTs Asy- Syafiiyah Kendari}

Mts Asy-Syafiiyah has a vision "to create a cheerful (smart, accomplished, Islamic, shady and beautiful) madrasa with an environmental perspective.

This vision illustrates the hopes of this school in the future which are of course related to the interests of students, society and the surrounding environment. This vision is expressed in school policies which in essence lead to the quality of education services. School policies concern the development of teacher competence, introduction of minal and student burns, and building partnerships with other institutions (IS-Interview, 2018).

The formulation of the vision and school policies is carried out by school leaders together with related elements. 
The vision of the school is a common hope, not only internally but also with parties outside the school, especially the community, so that in terms of content it must be able to touch various interests. The process of producing a vision through a deliberation process, including policies by school leaders (ISInterview, 2018).

\section{B. Supporting Factors for Improving the Quality of Education at MTs Asy-Syafiiyah Kendari.}

The rapid progress made at MTs Asy-Syafiiyah Kendari was greatly influenced by the leadership of the head of the madrasah.

The principal of madrasah always emphasizes the importance of service quality in carrying out their duties, for example the quality of learning by teachers starting from adequate preparation, implementation, to the evaluation process. Meanwhile, education personnel are encouraged to provide the best services such as speed, responsiveness to student needs, cleanliness, friendly to the community and so on (NFInterview, 2018).

Even so, awareness of quality for MTs Asy-Syafiiyah residents still needs more intense education. Because the unequal awareness and commitment of school residents to quality will interfere with the achievement of school goals.

\section{Impact of Strategy Implementation}

As a relatively new private religious school in Kendari, MTs Asy-Syafiiyah continues to show its passion for progress. Gradually this school can show its existence in society, not only in curricular activities but also in extra-curricular activities.

The efforts made by the leadership together with the ranks to build quality schools are starting to show results. Public trust increases every year of learning, graduates also experience an increase, and work partners also experience an increase. To align ourselves with equivalent schools, we have also started to carry out computer-based national exams (UNBK) (NFInterview, 2018). 


\section{Discussion}

\section{A. Principal Strategy}

Although strategy touches all levels of the organization, the concept starts with the idea of a leader (Karim, 2010). Strategy is a process that shows the direction to be directed by the organization as a driving force and other main factors that will help the organization manager in determining products, services, and markets for the organization in the future (Mukminin, 2014). Strategy is the placement of an organization's mission, placement of organizational goals by increasing external and internal strength, formulating policies and certain techniques to achieve goals and ensure their proper implementation so that the main goals and objectives of the organization will be achieved (Megawati, 2018). Strategy is related to working on various priorities in achieving the vision that has been announced. The formulation of these strategies will be related to the efforts and policies that need to be taken by madrasas to realize the various objectives that have been declared (Muhaimin, 2015).

Strategy is a way to achieve long term goals. The definition of strategy is a unified, broad and integrated plan that links the strategic advantage of the company with environmental challenges, which is designed to ensure that the main objectives of the company can be achieved through proper implementation by the organization (Syahrul, 2017). In general, strategy is the process of determining the top leaders' plans that focus on the long-term goals of the organization, along with the formulation of a means or efforts how to achieve these goals. Meanwhile, in particular, strategy is an action that is incremental (always increasing) and continuous, and is carried out based on the point of view of what customers expect in the future. Thus, strategy almost always starts with what can happen and not what happens. The occurrence of new market innovation speeds and changing consumer patterns that require core competencies (Nugroho, 2017).

So it can be concluded that strategy is a way to formulate a vision, mission, and how to achieve goals, both short, medium and long term goals.

The term head of madrasah consists of two words, namely head and madrasah. The word head means a leader in an organization, agency or institution. Meanwhile, madrasah is a madrasa or college usually based on Islam (Dinda, 2018). 
The principal is one of the components of education that has the most role in improving the quality of education. The principal is the person in charge of the implementation of education, school administration, coaching other education personnel, utilizing and maintaining facilities and infrastructure as well as supervisors at the school he leads (Mulyasa, 2007). When viewed from the teacher's requirements to become a school principal, the principal can be said to be a career ladder from a functional teacher position. If a teacher has the competence as a school principal and has met certain requirements or tests, the teacher can get the position of principal (Ekosiswoyo, 2016).

In simple terms the principal of a madrasah is someone who is given the task by his subordinates to lead a madrasah where the teaching and learning process is held in the madrasah (Wahjosumidjo, 1999). The head of the madrasah is the personal of the madrasah who is responsible for madrasah activities. Therefore a madrasa principal is required to have the ability to influence, direct and mobilize any available resources to achieve organizational goals (Purwanti, 2016).

So it can be said that the principal is a teacher who is given an additional task or trust to lead a madrasah.

It can be formulated that the strategy of the madrasah head is a set of methods and certain efforts made by the head of the madrasah in order to achieve the planned goals. In this case the strategy adopted by the head of madrasah includes policies of the head of madrasah in improving the quality of education.

Various studies have been conducted on the principal's strategy in school development, confirming that strategy is something that is absolutely owned by a principal. Among the findings are:

1. Desi Tri Rakhmawati conducted research on "Principals' Strategies in Developing Active Learning Competencies at SDN Gresikan, Kemiri, Purworejo". In this thesis it can be concluded that the principal's strategies in developing Active Learning competencies at SDN Gresikan, Kemiri, Purworejo include: (1) motivating teachers to always be creative and innovative; (2) assigning teacher assignments in accordance with their respective fields; (3) sending teachers to attend training, training, workshops and seminars; (4) strive for adequate learning media and infrastructure; (5) improve discipline (Rakhmawati, 2013). 
2. Sari Jumiati conducted a study on "Strategies for Madrasah Principals in Improving Competency in Reading Al-Qur'an for Teachers in MAN Karanganyar". From the results of these studies indicate that the competence of reading Al-Qur'an on teachers at MAN Karanganyar is good enough. There are $80 \%$ can read AlQur'an fluently, $10 \%$ is good enough and $10 \%$ still need guidance. Given these conditions, the head of the madrasah is responsible for the condition of the madrasah teacher he leads. The principal of the madrasa then uses a strategy to improve competence in reading $\mathrm{Al}$ Qur'an in MAN Karanganyar. First, the principal provides motivation about the virtue, benefits, and ease of reading the $\mathrm{Al}$ Qur'an. Second, it requires every teacher to participate in activities to improve competence in reading the Qur'an every month. Third, it requires every teacher who teaches the first hour to guide and guide students in reading the Al-Qur'an. Fourth, holding a selection test for reading Al-Qur'an for prospective madrasah teachers who want to work at MAN Karanganyar (Jumiati, 2014).

3. Rudi Setiawan with the study "Strategy of Madrasah Principals in Improving the Quality of Islamic Education in MTS Negeri Godean, Sleman, Yogyakarta" who found that (1) the role of the head of madrasah as an educator is to build good relationships and provide motivation to teachers, staff and students. As an administrator, namely making planning, organizing and directing. As a supervisor, he implements various methods and helps overcome the problems faced by the teacher. As a leader, namely building the vision, mission and strategy of the institution, having communication skills and the ability to make decisions; (2) improving the quality of Islamic education, namely teachers, teachers who have high education, including 4 teachers who have graduated from S2; (3) Supporting factors in improving the quality of education are teachers, curriculum, facilities and infrastructure. The relevance of the three studies above with the research being studied is that they both discuss the strategy of the madrasah principal (Setiawan, 2010).

The findings above are an indicator that the management of schools or madrasahs is very dependent on the principal, especially in carrying out strategic functions as the highest leadership. As the highest leader, the principal or madrasah must be able to play various 
roles in order to improve quality. Whether a madrasah is progressing or not is very dependent on the principal (Hasba, 2020).

The complexity of the role of the principal / madrasah is summed up in EMASLIM terms (educator, manager, administrator, supervisor, leader, innovator, and motivator).

Figure 1. Various Roles of School / Madrasah Principals

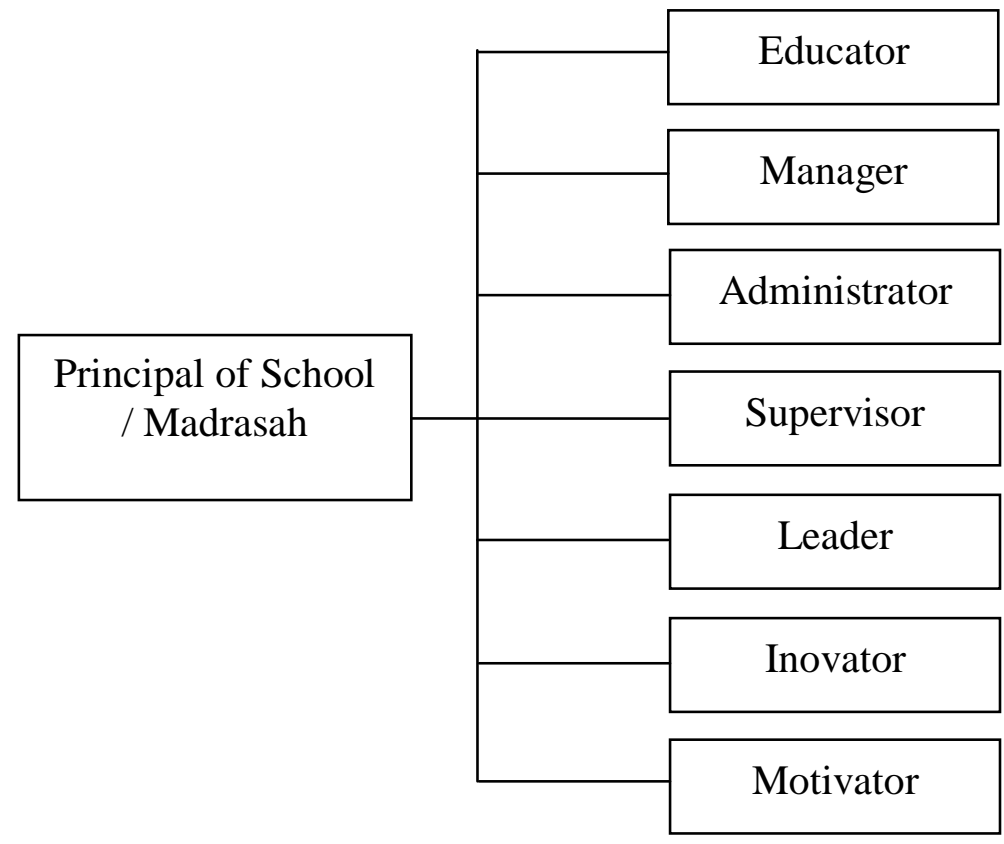

In general, school / madrasah principals are educators, where they start their careers as teachers. Therefore, in carrying out his duties as principal, it remains in an educational frame, not only for students but also for teachers and school staff. The principal of the madrasah must be able to show himself as a teacher figure, who deserves to be emulated (Kurnianingsih, 2018). Thus, the existence of a madrasah principal can be an energy that encourages the growth of work motivation so that there is an increase in the performance of teachers and staff (Septiana, Ngadiman \& Ivada, 2013).

Madrasah is an organization consisting of people who work together to achieve goals. The existence of the principal is to unite various organizational resources in order to achieve organizational goals. Therefore, the principal must be able to implement management functions which include: planning, organizing, mobilizing, and 
controlling (Terry \& Franklin, 1972). In practice, the principal of madrasah must be able to make school planning in the form of shortterm planning, mid-term planning, and long-term planning (Davoudi, 2015). The principal of the madrasah must also be able to organize in the form of: dividing work, determining work implementers, control limits, coordinating systems, and making organizational charts (Robbins, 1990). Control activities must also be carried out well, starting from the concept of control, an effective control system, and the implementation of controls in accordance with the times and the applicable regulations (Syahrul, 2018).

Consistency in the application of management functions is realized if there is regularity. In this context, the principal plays a role in creating various orders in the organization. Not only in office affairs, but regarding the regularity of various activities, inside and outside the organization. Good organizational arrangements will help in creating good governance (Salam, 2016). Good governance becomes a school instrument in increasing levels, for example to become an international standard school (Kusmayadi, Rusdiana \& Badruzaman, 2015).

Activities that have been structured and implemented must ensure compliance with the plans and standards that have been previously set. Therefore, the principal must be present in every school activity in carrying out supervisory tasks. Supervision in schools / madrasah includes academic and managerial supervision. Academic supervision is closely related to the development of teacher professionalism and improving the quality of learning (Suwartini, 2017). Sedangkan supervise manajerial dilakukan untuk mengetahui penerapan fungsi-fungsi manajerial (Sari, Bafadal \& Wiyono, 2018), dan juga perbaikan kinerja guru (Mudzakir, 2016).

The role of the principal does not always have to be in the shadow of an organizational structure or binding regulation. More than that, the principal must think outside the box in the form of breakthroughs and innovations. This is necessary so that schools will always appear competitive and different in providing educational services. As a leader, someone must appear as a differentiator (Bethel, 2012), and make changes (Boaz \& Fox, 2014). In uncertain times, a strategic leader who is able to compete in uncertain situations is needed (Syahrul, 2015). School leaders of Islamic schools, principals must be able to show prophetic leadership (Fadhli, 2019), a 
progressive leadership but still based on religious values (Syahrul, 2016).

As explained above, leaders must work beyond binding organizational structures and regulations. He must be able to make breakthroughs and innovations to bring schools to a higher and superior level. Studies show that schools that achieve excellence are due to innovative leadership (Syam, 2012). It is increasingly important to improve innovation in the 4.0 era (Asbari, Santoso \& Purwanto, 2019), where the work of the organization can no longer rely on manual devices, but rather based on applications and the internet of things (Wortmann \& Fluchter, 2015), (Atzori, Iera \& Morabito, 2010).

Principals of schools / madrasahs must be able to analyze various tasks in order to balance teamwork and individuals. In this context, the leader must always be a motivator (Andolsen, 2008). Willingness to work among members is an important psychological aspect. Therefore, leaders must be good coaches, and more importantly build their self-esteem (Castelli, 2008). School leaders not only face adults, but students who still need guidance towards maturity. So that school leaders seem destined to be motivators (Maehr, Midgley \& Urdan, 1992).

\section{B. Quality of Education}

Quality is a dynamic idea, not absolute. Quality is related to consumers or users of school education services. These consumers are people who use educational services at schools. If the quality of a school is good, there will be many people who want to enjoy educational services at that school. On the other hand, if the quality of the school is low, only a few people will be interested in the school (Masrokan, 2014).

Priyatna argues that education is an effort that is carried out deliberately and systematically to encourage, assist and guide someone to develop all their potential so that they achieve a better quality of self (Nurhamzah, Priatna, Hasanah \& Muntaha, 2018). Meanwhile, Marimba argues that education is a conscious guidance or leadership by educators of the physical and spiritual development of students towards the formation of the main personality (Marimba, 1989).

The correlation of quality with education is in line with the understanding expressed by Rohiat that the quality of education is an 
indicator to see productivity and is closely related to management or management problems in schools. Understanding the quality of education according to Permendiknas No. 23 of 2009 article 1 paragraph 1 is the level of intelligence of the nation's life that can be achieved from the implementation of the National Education System. This understanding directs that the quality of education in Indonesia will be achieved if it implements the provisions and scope of the National Education System in Law no. 20 of 2009 regarding the National Education Standards. In essence, quality in education includes input, process and output. Quality education inputs are quality teachers, quality students, quality curriculum, facilities and various aspects of providing quality education. Quality education process is a quality learning process. Quality education output is graduates who have the required competencies as well as graduates who are able to continue to a higher education level (Fadhli, 2017).

In the national context, the quality of education includes various aspects of education management, as covered by the national education standards. Several aspects related to quality standards in education management are:

1. Competency standards for graduates

2. Standard content

3. Standard process

4. Educators and education staff standards

5. Standard infrastructure

6. Financing standards

7. Assessment standards

8. School management standards (Umam, 2019)

\section{The Principal's Strategy in Improving the Quality of Education}

The quality of education in schools is largely determined by the presence of the principal (Fitrah, 2017). Strategies that can be taken by school principals in improving quality include: empowering teachers in school management activities, empowering school committees, increasing teacher professionalism, and supervising teaching in groups and individually. (Murniati \& Harun, 2015). A strategy that is quite effective in building the image of the school and becoming an indicator of school quality is to build school excellence (Hayudiyani, Saputra \& Adha, 2020). 
The quality of education in SMP / MTs can be improved in the following ways (Syafaruddin, 2002):

1. The principal must have and understand a clear work vision, be able and willing to work hard, have a high work drive, provide optimal service, and have strong work discipline..

2. Explore the competence and abilities of students.

3. Improve the competence and work profession of teachers, in seminars, workshops, MGMP, training, KKG, etc.

4. There is a fixed, but dynamic curriculum.

5. There is a good network of cooperation in the madrasa environment.

With these strategies, if the principal has the ability to implement it, the quality of education at a madrasah can improve. Research traditions can be developed in madrasas to obtain more valid and reliable information about internal and external conditions. Scientific method is highly recommended in order to maintain the quality of madrasas in a sustainable manner. This is an opportunity for madrasahs because schools rarely develop research traditions for institutional development.

Building quality in educational institutions is a complex effort, not only for the role of individual principals, but requires understanding and involvement of various parties. However, the position of the principal must be the center of change, starting from building a common vision and transforming the vision into organizational work. In this context, the vision of the school must clearly describe a commitment to quality, which is usually formulated into major future achievements. More specifically, a quality-oriented leader is needed (Herawan, 2016), and a quality culture (Said, 2018).

Entering the 4.0 era, a quality improvement strategy requires mastery of the latest technological devices (Fitriyah \& Santosa, 2020), one of them is by building a web-based school management (Laugi, 2018). The school website is not only an accessory, but completely functional, it can be developed as a database for decision making and supervision (Syahrul at al, 2019), making bulletin and online scientific journals, as well as measuring employee performance (Akib at al, 2020). Thus, the 4.0 era requires adaptive leadership and superior competence in the latest technology. The organizational vision must be in line with the spirit of 4.0 . 


\section{Conclusion}

Improving the quality of educational institutions is a systematic process. To arrive at tangible quality outputs, one must start with a conceptual idea, which is contained in a large-scale school planning or strategic plan document. In it will be seen the strategy of the leadership of educational institutions in achieving quality. The head of MTs Asy-Syafiyah has shown systematic steps starting from the formulation of a vision and policy, increasing the competence of teaching staff, recognizing the competence of students, and building partnerships. The leadership of the principal is a key factor in efforts to build a quality culture at MTs Asy-Syafiyah, so that it has an impact on improving the quality of graduates, increasing popularity in society, increasing work partners, paying attention to the interests of students, and improving teacher competence.

This study also recommends the need for further research on the processes of madrasah strategy formulation, the analytical model used to find the right strategy, and community involvement in the strategy formulation process.

\section{Acnowledgement}

This research was carried out because of the support of the school, especially the openness of the Principal of Asy-Syafiah Madrasah in providing the required information. Therefore, thanks to the Principal of Madrasah Asy-Syafiah for being open in sharing information with researchers. Thank you also to the residents of Madrasah Asy-Syafiah, in this case the teachers and staff at the madrasa. 


\section{Daftar Pustaka}

Akib, A., Karno, E., Erdiyanti, E., Syahrul, S., Badarwan, B., \& Murniati, M. (2020, April). The use of SIMPEG-based data mining techniques in measuring employee performance in Islamic higher education. In IOP Conference Series: Materials Science and Engineering (Vol. 830, No. 3, p. 032013). IOP Publishing.

Andolsen, A. A. (2008). The ingredients of a good leader: from analyzing the tasks at hand to balancing individual and team efforts, a leader must always be a motivator. Information Management Journal, 42(6), 41-46.

Asbari, M., Santoso, P., \& Purwanto, A. (2019). Pengaruh Kepemimpinan dan Budaya Organisasi Terhadap Perilaku Kerja Inovatif Pada Industri 4.0. JIM UPB (Jurnal Ilmiah Manajemen Universitas Putera Batam), 8(1), 7-15.

Atzori, L., Iera, A., \& Morabito, G. (2010). The internet of things: A survey. Computer networks, 54(15), 2787-2805.

Bafadal, I. (2016). Penilaian Kinerja Kepala Sekolah Sebagai Pemimpin Pembelajaran Dalam Rangka Peningkatan Akuntabilitas Sekolah. Manaj. Pendidik, 25(1), 1-9.

Bethel, S. M. (2012). Making a difference: Twelve qualities that make you a leader. AudioInk.

Boaz, N., \& Fox, E. A. (2014). Change leader, change thyself. McKinsey Quarterly, 11.

Burhan, B. (2007). Penelitian Kualitatif: Komunikasi, Ekonomi, Kebijakan Publik, dan Ilmu Sosial Lainnya. Jakarta: Prenada Media Group.

Andolsen, A. A. (2008). The ingredients of a good leader: from analyzing the tasks at hand to balancing individual and team efforts, a leader must always be a motivator. Information Management Journal, 42(6), 41-46.

Davoudi, S. (2015). Planning as practice of knowing. Planning Theory, 14(3), 316-331.

Dinda, P. (2018). Strategi Kepala Madrasah Dalam Meningkatkan Mutu Pendidikan Di Mts Al-Islam Jamsaren Surakarta Tahun Pelajaran 2017/2018 (Doctoral Dissertation, Iain Surakarta). 
Ekosiswoyo, R. (2016). Kepemimpinan kepala sekolah yang efektif kunci pencapaian kualitas pendidikan. Jurnal Ilmu Pendidikan Universitas Negeri Malang, 14(2).

Fadhli, M. (2017). Manajemen peningkatan mutu pendidikan. Tadbir: Jurnal Studi Manajemen Pendidikan, 1(2), 215-240.

Fadhli, M. (2019). Internalisasi Nilai-Nilai Kepemimpinan Profetik Dalam Lembaga Pendidikan Islam. At-Ta'dib: Jurnal Ilmiah Prodi Pendidikan Agama Islam, 116-127.

Fauzi, A. (2017). Kepemimpinan Kepala Madrasah Dalam Mengembangkan Lembaga Pendidikan Islam. Nidhomul Haq: Jurnal Manajemen Pendidikan Islam, 2(2), 53-64.

Fitrah, M. (2017). Peran kepala sekolah dalam meningkatkan mutu pendidikan. Jurnal Penjaminan Mutu, 3(1), 31-42.

Fitriyah, I., \& Santosa, A. B. (2020). KEPEMIMPINAN KEPALA SEKOLAH DALAM MENGHADAPI ERA REVOLUSI INDUSTRI 4.0 UNTUK MENINGKATKAN MUTU SEKOLAH. JMKSP (Jurnal Manajemen, Kepemimpinan, dan Supervisi Pendidikan), 5(1), 65-70.

Hasba, S. (2020). Peran-Peran Kepemimpinan dalam Peningkatan Kinerja di Lembaga Pendidikan Islam. Shautut Tarbiyah, 26(2), 272-295.

Hayudiyani, M., Saputra, B. R., Adha, M. A., \& Ariyanti, N. S. (2020). Strategi kepala sekolah meningkatkan mutu pendidikan melalui program unggulan sekolah. Jurnal Akuntabilitas Manajemen Pendidikan, 8, 89-95.

Herawan, E. (2016). Kepemimpinan Mutu Kepala Sekolah Dalam Peningkatan Mutu Pendidikan. PEDAGOGIA, 12(2), 51-59.

Iskandar, U. (2013). Kepemimpinan kepala sekolah dalam peningkatan kinerja guru. Jurnal Visi Ilmu Pendidikan, 10(1).

Jumiati, S. (2014) Strategi Kepala Madrasah Dalam Meningkatkan Kompetensi Membaca Al-Qur'an pada Guru di MAN Karanganyar, Skripsi: IAIN Surakarta.

Karim, M. (2010). Pemimpin transformasional di lembaga pendidikan islam.

Kurnianingsih, E. (2018). Peran Kepala Sekolah dalam Meningkatkan Kompetensi Guru. Indonesian Journal Of Education Management \& Administration Review, 1(1), 11-18.

Kusmayadi, D., Rusdiana, D., \& Badruzaman, J. (2015). Pemodelan 
Tata Kelola Sekolah Yang Baik Pasca Rintisan Sekolah Bertaraf Internasional (RSBI) di Kota Tasikmalaya. Sustainable Competitive Advantage (SCA), 5(1).

Laugi, S. (2018). Sistem Informasi berbasis Web dalam Penyelenggaran Lembaga Pendidikan. Shautut Tarbiyah, 24(1), 109-126.

Maehr, M. L., Midgley, C., \& Urdan, T. (1992). School leader as motivator. Educational Administration Quarterly, 28(3), 410429.

Marimba, A. D. (1964). Pengantar filsafat pendidikan Islam. Penerbit Alma Arif.

Masrokan, P. M. (2014). Manajemen Mutu Sekolah Strategi Peningkatan Mutu Dan Daya Saing Lembaga Pendidikan Islam.

Megawati, L. E. F. (2018). Strategi Menumbuhkan Jiwa Kewirausahaan yang Kreatif dan Inovatif. In Jurnal Prosiding Seminar Nasional ASBIS 2018 (pp. 296-302).

Miles, M. H., \& Huberman, A. A. 1984. Qualitative Data Analysis. Beverly Hills.

Muhaimin, M. A. (2015). Manajemen Pendidikan (Aplikasinya dalam Penyusunan Rencana Pengembangan Sekolah/Madrasah). Prenada Media.

Mukminin, A. (2014). Strategi Pembentukan Karakter Peduli Lingkungan di Sekolah Adiwiyata Mandiri. Ta'dib: Journal of Islamic Education (Jurnal Pendidikan Islam), 19(02), 227-252.

Mulyana, Y. (2014). Peran Kepala Sekolah Dasar dalam Pengembangan Profesionalisme Guru. TRIADIK, 12(1), 93-102.

Mulyasa, E. (2007). Menjadi kepala sekolah profesional. Bandung: Remaja Rosdakarya.

Mudzakir, D. (2016). Implementasi Supervisi Manajerial Dan Akademik Pengawas Dalam Meningkatkan Kinerja Guru Pendidikan Agama Islam Madrasah Ibtidayah. Studia Didaktika, 10(02), 33-47.

Murniati, A. R., \& Harun, C. Z. (2015). Strategi Kepala Sekolah Dalam Peningkatan Mutu di SD Negeri 1 Peukan Bada Aceh Besar. Jurnal Administrasi Pendidikan: Program Pascasarjana Unsyiah, 3(3).

Nugroho, W. D. (2017). Strategi Komunikasi Pemasaran Dalam Meningkatkan Minat Konsumen Steak Ranjang Bandung 
(Doctoral dissertation, PERPUSTAKAAN).

Nurhayati, N. (2019). Kepemimpinan Kepala Sekolah dan Dampaknya Terhdap Iklim Mengajar (Studi Kasus di SMPN 2 Kapetakan Cirebon). Gema Wiralodra, 10(1), 70-78.

Nurhamzah, N., Priatna, T., Hasanah, A., \& Muntaha, P. Z. (2018, October). Inheritance Model-Based Character Values of Local Wisdom. In International Conference on Islamic Education (ICIE 2018). Atlantis Press.

Purwanti, S. (2016). Peranan kepala madrasah terhadap kinerja guru. AL-IDARAH: Jurnal Kependidikan Islam, 6(1).

Rakhmawati, D.T. (2013). Strategi Kepala Sekolah Dalam Mengembangkan Kompetensi Active Learning Di SDN Gresikan, Kemiri, Purworejo. Skripsi: IAIN Surakarta.

Davoudi, S. (2015). Planning as practice of knowing. Planning Theory, 14(3), 316-331.

Said, A. (2018). Kepemimpinan Kepala Sekolah Dalam Melestarikan Budaya Mutu Sekolah. Journal EVALUASI, 2(1), 257-273.

Salam, R. (2016, September). Penerapan Fungsi Administrasi Perkantoran Modern berbasis Daya Saing Organisasi dalam menyongsong MEA 2015. In Prosiding Seminar Nasional Himpunan Sarjana Ilmu-ilmu Sosial (Vol. 1, No. 1, pp. 186190).

Sari, D. N. A., Bafadal, I., \& Wiyono, B. B. (2018). Pelaksanaan Supervisi Manajerial dalam Rangka Implementasi Manajemen Berbasis Sekolah. JAMP: Jurnal Administrasi dan Manajemen Pendidikan, 1(2), 213-221.

Septiana, R., Ngadiman, N., \& Ivada, E. (2013). Pengaruh kepemimpinan kepala sekolah dan motivasi kerja terhadap kinerja guru SMP Negeri Wonosari. Jurnal Pendidikan Ekonomi Universitas Sebelas Maret, 2(1), 13537.

Setiawan, R. (2010). Strategi Kepala Madrasah Dalam Meningkatkan Kompetensi Membaca Al-Qur'an pada Guru di MAN Karanganyar, Skripsi: UIN Sunan Kalijaga Yogyakarta.

Setiyati, S. (2014). Pengaruh kepemimpinan kepala sekolah, motivasi

Kerja, dan budaya sekolah terhadap kinerja guru. Jurnal Pendidikan Teknologi dan Kejuruan, 22(2), 200-206.

Sugiyono, D. (2010). Metode penelitian kuantitatif dan R\&D. Bandung: Alfabeta. 
Sulistiya, M. (2013). Pengaruh Kepemimpinan Kepala Sekolah Terhadap Kinerja Guru. Ekonomi IKIP Veteran Semarang, 1(2).

Suwartini, E. A. (2017). Supervisi akademik kepala sekolah, profesionalisme guru dan mutu pendidikan. Jurnal administrasi pendidikan, 24(2), 62-70.

Syafaruddin. (2002). Manajemen mutu terpadu dalam pendidikan: Konsep, strategi, dan aplikasi. Gramedia Widiasarana Indonesia.

Syahrul, S. (2013). Penelitian sebagai Instrumen Perbaikan Kualitas Kinerja Organisasi Pendidikan secara Berkelanjutan (Continuous Improvement). Al-Ta'dib, 6(1), 150-163.

Syahrul, S. (2015). Kepemimpinan dan Inovasi Lembaga Pendidikan (Pengalaman Pondok Gontor VII Putra Sulawesi Tenggara). AlTa'dib, 8(1), 82-100.

Syahrul, S. (2017). Perencanaan Strategis dan Praktiknya di Perguruan Tinggi. Shautut Tarbiyah, 23(1), 142-159.

Syahrul, S. (2018). Pedoman Satuan Pengawas Internal (SPI) Institut Agama Islam Negeri (IAIN) Kendari.

Syahrul, S. (2015). Mengelola Perguruan Tinggi dalam Iklim Ketidakpastian (Memahami Dinamika Perencanaan Strategis di STAIN Sultan Qaimuddin Kendari). Al-Izzah: Jurnal HasilHasil Penelitian, 10(1), 143-160.

Syahrul, S. (2016). KEPEMIMPINAN RELIGIOTRANSFORMASIONAL: ALTRUISME KIAI DALAM MEMBANGUN KARAKTER DAN BUDAYA PM GONTOR VII PUTRA SULAWESI TENGGARA.

Syahrul, S., Alim, N., Pairin, P., \& Nur, J. (2019). Utilization of management information systems in managerial supervision at IAIN Kendari. International Journal of Recent Technology and Engineering (TM), 8(1C2), 392-392.

Syam, A. (2012). Kepemimpinan Pendidikan yang Inovatif. Al-Ta lim Journal, 19(2), 151-157.

Terry, G. R., \& Franklin, S. G. (1972). Principles of management (p. 516). Homewood, IL: RD Irwin.

Triyanto, E., Anitah, S., \& Suryani, N. (2013). Peran kepemimpinan kepala sekolah dalam pemanfaatan media pembelajaran sebagai upaya peningkatan kualitas proses pembelajaran. Teknologi Pendidikan, 1(2), 226-238. 
Umam, M. K. (2019). Peningkatan Mutu Pendidikan Melalui Manajemen Peserta Didik. Al-Hikmah: Jurnal Kependidikan Dan Syariah, 6(2), 62-76.

Wahjosumidjo. (1999). Kepemimpinan kepala sekolah: tinjauan teoritik dan permasalahannya. Rajagrafindo Persada (Rajawali Pers).

Wortmann, F., \& Flüchter, K. (2015). Internet of things. Business \& Information Systems Engineering, 57(3), 221-224. 